\title{
The Impact of Tax Deduction Ratio Reduction on Dividend Payouts Under the Integrated Tax System: Evidence From Taiwan
}

\author{
Sue-Tzeng Chuang ${ }^{1}$, Ying-Hsiang Chen ${ }^{2}$, Ching-Chieh $\operatorname{Lin}^{3} \&$ Wen-Chih Lee ${ }^{4}$ \\ ${ }^{1}$ Department of Accounting, I-Shou University, Kaohsiung City, Taiwan, R.O.C. \\ ${ }^{2}$ Department of International Business, National Kaohsiung University of Science and Technology, Kaohsiung City, \\ Taiwan, R.O.C. \\ ${ }^{3}$ Department of Accounting, National Pingtung University, Pingtung City, Pingtung County, Taiwan, R.O.C. \\ ${ }^{4}$ Department of Wealth and Taxation Management, National Kaohsiung University of Science and Technology, \\ Kaohsiung City, Taiwan, R.O.C. \\ Correspondence: Ching-Chieh Lin, No.51, Minsheng E. Rd., Pingtung City, Pingtung County 90004, Taiwan, R.O.C. \\ Tel: 886-930-830-354.
}

Received: April 18, 2018

Accepted: May 21, 2018

Online Published: May 24, 2018

doi:10.5430/ijfr.v9n3p26

URL: https://doi.org/10.5430/ijfr.v9n3p26

\begin{abstract}
Taiwan passed the Robust Financial Administrative System in 2014. Regarding the imputation tax system, the tax credit of imputation was reduced from $100 \%$ to $50 \%$, effective in 2015 . In other words, contrary to the year 2014 , only the half of tax paid by companies can be used by individuals to offset personal income taxes under the new system. The purpose of this study is to investigate whether dividend payouts are influenced by this tax reform. In addition, whether the companies known for stable dividends have changed their dividend payout ratios. Results show that the dividend payout ratios decreased after the tax reform was reduced, indicating that companies used this tax reform to enact tax planning for stockholders. This study also finds that companies offering stable dividends maintain similar dividend policies in the dividend payout ratios.
\end{abstract}

Keywords: tax deduction ratio, dividend payout, tax planning, Taiwan

\section{Introduction}

To eliminate the double taxation on the enterprise income at the company level and on the personal incomes at the shareholder level, the Taiwanese government started to implement the imputation tax system in 1998. Under this system, the corporate taxes paid by the company level can offset the tax liability of dividends on the personal incomes of shareholders. The system in Taiwan was full imputation where the corporate income taxes paid could be used $100 \%$ to offset the personal tax liabilities. Therefore, the level of tax rates depends on the tax rates applicable for the personal income taxes of shareholders.

However, on May 16, 2014, Taiwan Legislative Yuan passed its third reading of the law amendments in relation to the Robust Financial Administrative System (the ACT, thereafter). Regarding the imputation tax system, the tax credit of imputation was reduced from $100 \%$ to $50 \%$, effective in 2015 . According to the Ministry of Finance, the reduction of tax credits from $100 \%$ to $50 \%$ will increase the tax revenue by NT\$ 50.5 billion (U.S. 1.74 billion) per annum. The reduction in tax credits increases tax liabilities for most of the shareholders who receive dividends. The ACT was passed in 2014 and took effect in 2015. In other words, the year 2014 was the last window of opportunity to pursue relevant tax efficiency. If a company had distributed earnings in 2014 , it would be possible to avoid the impact of the $50 \%$ tax credit reduction in 2015.

Prior studies suggest that tax reforms prompt companies to engage in tax planning. For example, the U.S. government lowered the corporate income tax from $46 \%$ to $34 \%$ in September 1985. As a result, companies started earnings management to reduce tax burdens (e.g. Scholes, Wilson, \& Wolfson, 1992; Guenther 1994; Maydew 1997; Lopez, Reiger, \& Lee, 1998). The alternative minimum taxation system implemented in the U.S. in 1987 was another example. Literature suggests that companies are engaged in tax planning by increasing the taxable incomes the year before the system and reducing the taxable incomes during the first year of the new system (Gramlich, 1991; Dhaliwal \& Wang, 1992; Manzon, 1992; Wang, 1994). 
Research indicates that companies have increased dividends to engagement in tax planning as the imputation tax system commenced. For example, Canada (Khoury \& Smith, 1977), U. K. (Poterba \& Summers, 1984), and Australia (Pattenden \& Twite, 2008). However, Lintner (1956) posits that taxations are not the primary concern for dividend distributions. In fact, management focuses on the stability of dividends because this enhances the investors' evaluations of the companies (Alli, Khan, \& Ramirez, 1993). Many studies suggest that stable dividends are a key consideration for dividend policies (Baker, Farrelly, \& Edelman, 1985; Brav, Graham, Harvey, \& Michaely, 2008).

In sum, this paper intends to explore the following issues. First, whether the tax credit cut from $100 \%$ to $50 \%$ in the imputation tax system has altered the dividend distributions by companies. Second, whether the companies known for stable dividends have changed their dividend policies.

\section{Literature Review and Hypothesis Development}

\subsection{Integrated Tax System in Taiwan}

The single-entity approach in taxation in Taiwan was changed into the imputation tax system in 1998 in order to avoid double taxation. Under this system, the income taxes paid by corporates can fully deduct the income tax liabilities for individuals. Therefore, the tax rate on dividend incomes depends on the tax bracket of shareholders. However, Taiwan passed the law amendments regarding the imputation tax system on May 16, 2014, the tax credit of imputation was reduced from $100 \%$ to $50 \%$, effective in 2015.

\subsection{Tax Planning Research Under Tax Reform}

In September 1986, the U.S. government passed a tax reform act to gradually lower corporate income tax rate from $46 \%$ to $34 \%$. Scholes et al. (1992) examine whether the companies following the calendar year system have accelerated cost recognitions or deferred revenue recognition in 1986-1987 to reduce income tax burdens, given their expectations for declining tax rates. The study finds that companies deferred the incomes in the fourth quarter of 1986 to the first quarter of 1987 in order to apply a lower tax rate. Guenther (1994) refers to the current discretionary accruals as an indicator of earnings management. The regression analysis shows that companies report a lower level of current discretionary accruals during the year before the income tax reductions. Meanwhile, there is a positive correlation between long-term liabilities and current discretionary accruals. This suggests the presence of earnings management before meaningful reductions of income tax rates. Maydew (1997) samples the companies suffering net operating losses and the empirical research indicates that the companies defer gross profits from the year with net operating losses into the following year, and bring forward the sales and administrative expenses of the next year into the current year with net operating losses. Lopez et al. (1998) contend that the companies with an aggressive approach to tax reporting recognize a higher level of negative current discretionary accruals before the cut in income tax rates. In addition, there is a positive correlation between the degree of recognitions and the magnitude of the income tax rate reductions. These studies suggest that the tax reforms in the U.S. in 1986 have triggered tax planning by companies.

The U.S. government began the alternative minimum taxation system in 1987. Gramlich (1991) finds that the companies affected by the system pumped up the net incomes using discretionary accruals during the year before the new rules. The purpose is to lower the net incomes during the first year of the new system and to reduce tax burdens. Dhaliwal and Wang (1992) posit that companies manage earnings by levering the temporary and permanent difference in taxation. According to the empirical analysis by Wang (1994), companies inflated earnings by reducing accrual expenses and increasing accrual incomes during the year before the effectiveness of the alternative minimum tax system. Subsequently, they lowered the tax burden during the first year of the new system by reducing accrual incomes and increasing accrual expenses. Manzon (1992) examines a total of 151 non-financial companies and the results show that companies adopt the accruals-based earnings management in relation to long-term assets to reduce the tax burdens under the alternative minimum tax system. The conclusion is that the effectiveness of the alternative minimum tax system has resulted in tax planning.

Germany is another country that operates imputation tax system. In 2001, the German government lowered the 100\% tax credits into 50\%, effective in 2002. Kaserer, Rapp, and Trinchera (2012) indicate that the increase in dividend tax burdens has reduced the tendency and magnitude of dividend distributions by companies. Finland lowered the full tax credits in 2004 to partial tax credits as well. Whilst the corporate income tax rate was reduced from $29 \%$ to $26 \%$ and the personal income tax rate was cut from $29 \%$ to $28 \%$, the personal income tax for dividend incomes increased from $0 \%$ to $19.6 \%$ (i.e. $70 \% \times 28 \%$ ) because only $30 \%$ of the dividend incomes are tax free. Korkeamaki, Liljeblom, and Pasternack (2010) state that in Norway where the $100 \%$ tax credits were also reduced to partial tax credits and the highest personal income tax rate for dividend incomes were raised from $0 \%$ to $28 \%$, companies have scaled back 
in dividend distributions. According to Alstadsater and Fjarli (2009), the dividend payouts by Norwegian companies were reduced by $41 \%$ in 2006. This suggests strong timing effects on the dividend policies. Daunfeldt, Selander, and Wikstrom (2009) explore the impact of the tax reforms in Sweden and find that changes in taxation affect dividend distributions.

Therefore, this paper contends that the reduction in the tax credits from $100 \%$ to $50 \%$ will result in increased dividend payout ratios immediately before the ACT and decreased in dividend payout ratios shortly after the ACT. We thus develop the following hypotheses:

H1: Ceteris paribus, companies increase dividend payout ratios before the ACT and decrease dividend payout ratio after the ACT.

Allen, Bernardo, and Welch (2000) develop the clientele effect theory and posit that companies should establish dividend policies to attract a specific group of investors. Lintner (1956) believes that the management should focus on the stability of dividends and taxations should not be a priority in the consideration for dividend policies. This is because stable dividends enhance the investors' valuations of the firms (Alli et al. 1993). Brav et al. (2008) conduct a survey and indicate that the primary concern for dividend policies is the historical payouts. Taxation is a secondary issue. Many studies argue for the importance of dividend stability to dividend policies (Baker et al. 1985; Brav et al. 2008). This paper hence establishes the following hypotheses:

$\mathrm{H} 2$ : Ceteris paribus, the companies with stable dividends report the similar dividend payout ratios before and after the ACT.

\section{Research Method}

\subsection{Data and Sample Selection}

The purpose of this paper is to explore the impact of the tax credit cut from $100 \%$ to $50 \%$ in 2015 on corporate dividend policies under the imputation tax system. As the amendment was passed in May 2014, the tax planning via dividend distributions should have occurred in the year 2014-2015. Therefore, this paper selects the dividend distributions in 2014-2015 as the research period and the prior year 2013-2014 for financial data.

This paper samples the companies listed in Taiwan Stock. The sampled companies should meet the following criteria: (1) the issue of dividend in either 2014 or 2015 as it is impossible to observe the tax planning associated with dividend distributions if the companies did not pay out dividend; (2) the financial and insurance industries are excluded due to unique system of business; (3) full-cash delivery stocks, managed stocks or the companies in financial distress are also excluded; (4) the companies with missing or unreasonable values are excluded. In total, this paper selects 1,661 observations of company/year, comprised of 790 observations before the cut in tax credits and 871 observations after the cut in tax credits. All the variables are retrieved from the database of Taiwan Economic Journal.

\subsection{Empirical Model}

$\mathrm{H} 1$ examines the dividend payout ratio before and after the reduction of tax credits. The empirical model below is established on the basis of the literature review and the estimates are made with ordinary least squares (Brown and Sum 2010; Korkeamaki et al. 2010):

$$
\begin{aligned}
\operatorname{CashD}_{i t}= & \beta_{0}+\beta_{1} \text { YEAR }_{i t}+\beta_{2} \operatorname{DivP}_{i t}+\beta_{3} \text { LagCashD }_{i t}+\beta_{4} \text { GROW }_{i t}+\beta_{5} F_{\text {FCF }}+\beta_{6} \text { CF }_{i t}+\beta_{7} \text { SIZE }_{i t} \\
& +\beta_{8} \text { DEBT }_{i t}+\beta_{9} \text { ROA }_{i t}+\beta_{10} \text { LagROA }_{i t}+\beta_{11} \text { STOCK }_{i t}+\beta_{12} P_{-} A P P_{i t}+\beta_{13} \text { RETE }_{i t} \\
& +\varepsilon_{i t}
\end{aligned}
$$

Where,

CashD: cash dividend payout ratios, i.e. cash dividends per share divided by earnings per share, shown in percentage;

YEAR: the dummy variable for the year before or after the cut in tax credits. The year 2014 before the cut is defined as 1 ; the year 2015 after the cut is defined as 0 ;

DivP: the stability of dividends, defined as the standard deviation of the dividend payout ratios according to the first five years of the financial data (2008-2012) for Company $i$;

LagCashD: prior cash dividend payout ratios, i.e. prior-year cash dividends per share divided by earnings per share in the same year, shown in percentage; 
GROW: growth opportunity, defined as the annual growth rate of net sales;

$F C F$ : free cash flows, calculated as the operating cash flows less capital expenditure and then divided with total assets at the end of the year before dividend distributions, shown in percentage;

$C F$ : capital adequacy, calculated as the current assets divided with total assets at the end of the year before dividend distributions, shown in percentage;

SIZE: firm size, defined as the natural logarithm of the total assets at the end of the year before dividend distributions;

DEBT: leverage ratio, calculated with the total liabilities divided with the total assets at the end of the year before dividend distributions, shown in percentage;

ROA: return on assets as a measure of profitability, calculated as the sum of net incomes and post-tax interest expenses divided with the average total assets of the year before dividend distributions, shown in percentage;

LagROA: prior return on assets, calculated as the sum of prior-year net incomes and post-tax interest expenses divided with the average total assets of the same year before dividend distributions, shown in percentage;

STOCK: the percentage of ownership by major shareholders, calculated with the total ownership of the top 10 shareholders at the end of the year before dividends, shown in percentage;

$P \_A P P:$ stock price appreciation, calculated as the average monthly stock price increase over the last 12 months, shown in percentage;

RETE: life-cycle stage, calculated as the retained earnings divided with total common equity, shown in percentage;

$\varepsilon:$ the residual term.

The lower script $i$ sign in the model indicates the individual company in the sample, the lower script $t$ indicates the year in the regression model before or after the cut in tax credits.

The dependent variable, CashD (dividend payout ratios), is used to proxy for dividend policy. Prior studies examine dividend policies using the dummy variable of dividend payouts (Alstadsater \& Fjarli, 2009; Kaserer et al. 2012; Wang \& Guo, 2011), or dividend yields (Nam, Wang, \& Zhang, 2010). However, majority of studies refer to the payout ratio, i.e. dividend per share divided by earnings per share (Lintner, 1956; Papaioannou \& Savarese, 1994; Lasfer, 1996; Howton \& Howton, 2006; Korkeamaki et al., 2010; Hoque, 2018). Therefore, this paper uses the dividend payout to quantify dividend policies.

The main independent variable is YEAR (the dummy variable indicating before or after the ACT). YEAR is defined as 1 if before the ACT, 0 otherwise. YEAR is the key variable for H1. If the dividend payout ratios increase before the reduction in tax credits and decreases after the reduction in tax credits, the coefficient of $Y E A R$ should be positive.

The control variables are suggested by prior research and analysed below:

Studies suggest that the stability of dividends usually means a high probability of future dividends. The reverse is also true (Alli et al. 1993). Therefore, there is a positive correlation between dividend stability (DivP) and payout ratios. Many studies refer to the dividend payout ratio during the previous year as the proxy variable for dividend stability (Lasfer 1996). However, the dividend payout ratio during the prior year is only capturing the effects of the lagged variable. Some studies use the mean dividend payout ratios over multiple years as the proxy variable for dividend stability (Alli et al. 1993). However, this in fact measures the percentage of dividend payouts, not the stability of dividend streams. This paper hence argues that the more appropriate measurement should be the standard deviation of the dividend payout ratios over multiple years. We use five years of the financial data (2008-2012) to calculate the dividend stability. The higher the $\operatorname{Div} P$ value, the less stable the dividend streams.

Following Lintner (1956), the lagged payout ratio (LagCashD) and lagged ROA (LagROA) are included. Both variables are positively related to current payout ratios as predictied by Lintner (1956). The greater the growth opportunities $(G R O W)$, the more the investment opportunities, the higher the demand for cash and the less the disposable cash (Hoque, 2018). Brown and Sum (2010) indicate that the companies with ample opportunities to invest will retain earnings and refrain from distributing cash dividends. Therefore, this paper includes $G R O W$ as the control variable and expects a negative correlation between growth opportunities and dividend payout ratios. Free cash flows $(F C F)$ are the cash flows derived from operating activities, less capital expenditures required to maintain or expand capacities. Free cash flows are available to repay debts or issue dividends. Literature indicates that the companies with high free cash flows tend to release dividends in order to mitigate agency problems (Jensen 1986; Thanatawee, 2011). Therefore, this paper expects a positive coefficient of $F C F$. Research suggests that the 
availability of internal capital is the key concern for the distribution of cash dividends (Brav et al. 2008). Hence, this paper expects a positive correlation between capital adequacy $(C F)$ and dividend payout ratios. We use the natural logarithm of the total assets of a company as the proxy variable for firm size (SIZE), which examines the effect on dividend distributions. In theory, large companies have better access to funding and are able to distribute more cash dividends (Howton \& Howton 2006). This paper expects the larger the company, the higher the cash dividend payout ratios. There are agency problems between creditors and shareholders. To control the transfer of wealth to shareholders via dividends, creditors usually impose restrictions via debt covenants on cash dividends. This paper expects the higher the debt ratio (DEBT), the lower the dividend payout ratios (Thanatawee, 2011). The higher the profitability $(R O A)$, the greater the undistributed earnings and the better the capacity to issue dividends. Mitton (2004) indicates that highly profitable companies tend to distribute dividends. Hence, this paper expects profitability to be positively correlated with dividend payout ratios. We also include STOCK (the percentage of ownership by major shareholders) to control the effect of major shareholders on dividend payouts (Korkeamaki et al., 2010; Nam et al., 2010; Jacob \& Jacob, 2013). Lie and Lie (1999) and Moser (2007) argue that companies with high stock price appreciation in the prior year have a higher propensity to pay dividends. As a result, we include stock price appreciation $\left(P_{-} A P P\right)$. To control for the life-cycle model of dividends suggested by DeAngelo, DeAngelo, and Stulz (2006), we include the fraction of retained earned relative in a companies' common equity (RETE).

$\mathrm{H} 2$ explores whether the companies known for stable dividends maintain their dividend payout ratios regardless of the reduction in tax credits. We rearrange Eg. (1), into the following:

$$
\begin{aligned}
\operatorname{CashD}_{i t}=\beta_{0}+ & \beta_{1} \text { YEAR }_{i t}+\beta_{2} \text { DivP }_{i t}+\beta_{3} \operatorname{DivP} \times \text { YEAR }_{i t}+\beta_{4} \text { LagCashD }_{i t}+\beta_{5} \text { GROW }_{i t}+\beta_{6} F C F_{i t}+\beta_{7} \text { CF }_{i t} \\
& +\beta_{8} \text { SIZE }_{i t}+\beta_{9} D E B T_{i t}+\beta_{10} R O A_{i t}+\beta_{11} \text { LagROA }_{i t}+\beta_{12} \text { STOCK }_{i t}+\beta_{13} P_{-} A P P_{i t}+\beta_{14} \text { RETE }_{i t} \\
& +\varepsilon_{i t}
\end{aligned}
$$

Where,

DivP $\times Y E A R$ is the product of DivP (stability of dividends) and YEAR (the dummy variable to indicate before or after the ACT);

Other variables are defined as the same as Eq. (1).

We expect the coefficient to be not statistically significant for the product of DivP and YEAR in Eq. (2) if the companies with stable dividends maintain their existing dividend payout ratio regardless of the drop in tax credits.

\section{Results}

\subsection{Descriptive Statistics}

Table 1 summarizes the descriptive statistics of all the variables before and after the ACT. The mean of the dividend payout ratios $($ CashD $)$ is $87.00 \%$ before the ACT and $78.13 \%$ post the ACT. The reduction is by $8.87 \%$, which are consistent with H1. Besides, the t-test indicated that the p-value is also statistically significant under the 5\% significance level (not shown in the table).

The mean of the stability of dividends (DivP) is $45.87 \%$ before the ACT and $47.64 \%$ afterwards. Prior cash dividend payout ratios ( $\operatorname{Lag} C a s h D)$, growth opportunities $(G R O W)$, prior profitability ( $\operatorname{LagROA})$, and stock price appreciation $\left(P \_A P P\right)$ increases but free cash flows $(F C F)$ drop post the ACT. None of the capital adequacy $(C F)$, firm sizes $(S I Z E)$, leverage ratios $(D E B T)$, profitability $(R O A)$, and ownership of major shareholders $(S T O C K)$, and life-cycle stage (RETE) report any noticeable variation after the reduction of tax credits.

Table 1. Descriptive statistics

\begin{tabular}{lrrrrrrrr}
\hline & \multicolumn{3}{c}{ Before tax credit cut (2014) } & \multicolumn{4}{c}{ After tax credit cut (2015) } \\
\cline { 2 - 9 } Variable & Mean & SD & Min. & Max. & Mean & SD & Min. & Max. \\
\hline CashD & 87.00 & 85.82 & 2.29 & 625.00 & 78.13 & 61.71 & 0.98 & 625.00 \\
YEAR & 1.00 & 0.00 & 1.00 & 1.00 & 0.00 & 0.00 & 0.00 & 0.00 \\
DivP & 45.87 & 206.68 & 0.00 & $4,885.17$ & 47.64 & 133.20 & 0.00 & $2,236.07$ \\
LagCashD & 62.36 & 45.91 & -80.00 & 387.93 & 71.88 & 63.60 & -80.00 & 387.93 \\
GROW & 5.79 & 43.05 & -65.72 & 354.96 & 9.38 & 37.95 & -65.72 & 354.96
\end{tabular}




\begin{tabular}{|c|c|c|c|c|c|c|c|c|}
\hline$F C F$ & 5.32 & 9.27 & -45.72 & 66.58 & 4.16 & 8.43 & -42.49 & 66.88 \\
\hline$C F$ & 31.33 & 18.27 & 0.03 & 89.47 & 31.31 & 18.05 & 0.02 & 88.53 \\
\hline SIZE & 15.53 & 1.32 & 12.53 & 21.42 & 15.54 & 1.33 & 12.73 & 21.62 \\
\hline$D E B T$ & 33.85 & 15.23 & 1.39 & 78.25 & 33.70 & 15.12 & 1.00 & 80.41 \\
\hline$R O A$ & 7.74 & 6.30 & 0.08 & 82.22 & 7.66 & 5.65 & 0.04 & 39.83 \\
\hline LagROA & 6.57 & 6.37 & -19.40 & 44.44 & 6.97 & 7.20 & -62.02 & 82.22 \\
\hline STOCK & 21.11 & 11.23 & 0.01 & 79.81 & 21.12 & 11.05 & 0.68 & 79.80 \\
\hline$P \_A P P$ & 1.91 & 2.41 & -6.53 & 22.31 & 2.44 & 3.14 & -13.15 & 18.60 \\
\hline RETE & 20.07 & 13.79 & -26.82 & 83.65 & 20.38 & 13.69 & -35.07 & 83.48 \\
\hline observations & \multicolumn{4}{|c|}{790} & \multicolumn{4}{|c|}{871} \\
\hline
\end{tabular}

Variable definitions: CashD: cash dividend payout ratios, i.e. cash dividends per share divided by earnings per share, shown in percentage; YEAR: the dummy variable for the year before or after the cut in tax credits. The year 2014 before the cut is defined as 1; the year 2015 after the cut is defined as 0 ; DivP: the stability of dividends, defined as the standard deviation of the dividend payout ratios according to the first five years of the financial data (2008-2012) for Company $i$; LagCashD: prior cash dividend payout ratios, i.e. prior-year cash dividends per share divided by earnings per share in the same year, shown in percentage; GROW: growth opportunity, defined as the annual growth rate of net sales; $F C F$ : free cash flows, calculated as the operating cash flows less capital expenditure and then divided with total assets at the end of the year before dividend distributions, shown in percentage; $C F$ : capital adequacy, calculated as the current assets divided with total assets at the end of the year before dividend distributions, shown in percentage; SIZE: firm size, defined as the natural logarithm of the total assets at the end of the year before dividend distributions; $D E B T$ : liability ratio, calculated with the total liabilities divided with the total assets at the end of the year before dividend distributions, shown in percentage; ROA: return on assets as a measure of profitability, calculated as the sum of net incomes and post-tax interest expenses divided with the average total assets of the year before dividend distributions, shown in percentage; LagROA: prior return on assets, calculated as the sum of prior-year net incomes and post-tax interest expenses divided with the average total assets of the same year before dividend distributions, shown in percentage; STOCK: the percentage of ownership by major shareholders, calculated with the total ownership of the top 10 shareholders at the end of the year before dividends, shown in percentage; $P \_A P P$ : stock price appreciation, calculated as the average monthly stock price increase over the last 12 months, shown in percentage; RETE: life-cycle stage, calculated as the retained earnings divided with total common equity, shown in percentage.

\subsection{Correlation Analysis}

Table 2 shows the coefficients and p-values of all the variables. The dummy variable $(Y E A R)$ is positively correlated with the dividend payout ratios (CashD), which is in line with H1. Meanwhile, the stability of dividends (DivP) and prior payout ratios (LagCashD) are positively correlated with the dividend payout ratios (CashD). Free cash flow $(F C F)$ and capital adequacy $(C F)$ are positively correlated with the dividend payout ratios, but not statistically significant under the $10 \%$ significance level. Firm sizes (SIZE) is inversely correlated with the dividend payout ratios, indicating that large companies pay out a smaller percentage of dividends. The growth opportunities $(G R O W)$ and leverage ratio $(D E B T)$ are negatively correlated with the dividend payout ratios. This implies that highly growth or levered companies need to retain earnings or repay heavy interests and do not have much leeway to issue cash dividends. Profitability ( $R O A$ and $L a g R O A$ ) is negatively correlated with the dividend payout ratios. This is possibly because the highly profitable companies are still in the growth period and need to reserve cash to fund future growth, instead of returning cash to shareholders. As all the correlation coefficients of the independent variables are smaller than 0.65 , the collinearity problem is unlikely to be significant (Anderson, Sweeney, \& Williams, 1999). 
Table 2. Correlation analysis

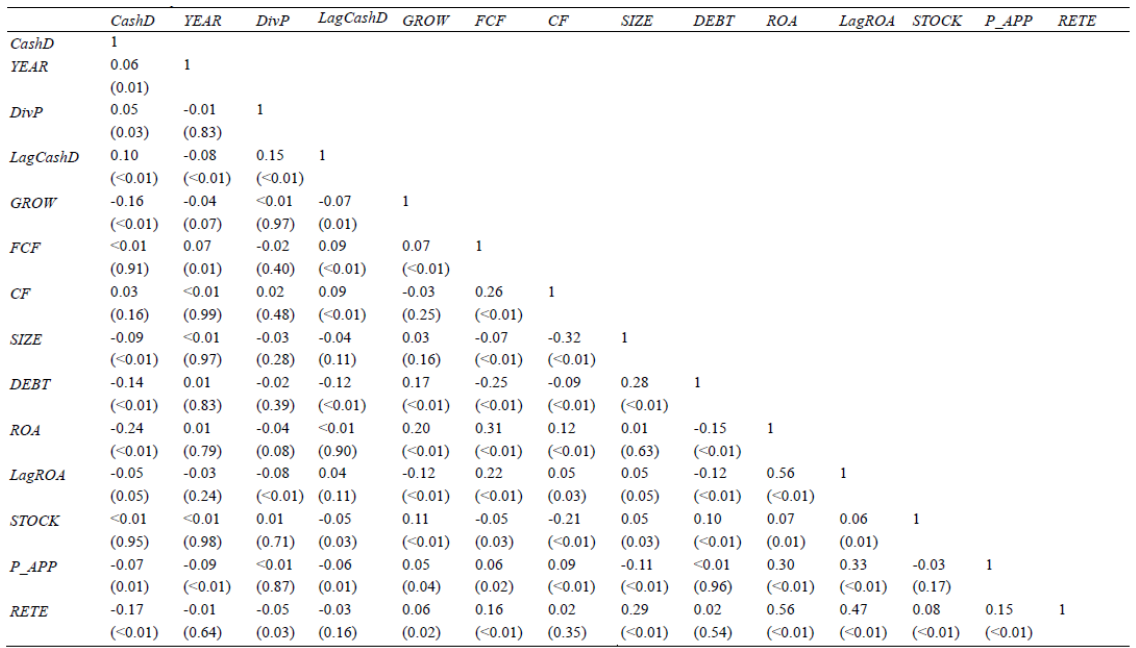

Please see Table 1 for variable definitions.

\subsection{Regression Analysis}

Tables 3 presents the regression results on the dividend payout ratios. The F-value is statistically significant under the $1 \%$ significance level. This suggests that all the independent variables in aggregation have explanatory power over dependent variables. The YEAR is positively related to the dividend payout ratios and statistically significant under the $1 \%$ significance level, implying that the sampled companies increase dividend payouts immediately after the tax credit reduction and decrease dividend payouts post the tax credit cut, in order to facilitate the tax planning by shareholders. Hence, H1 is supported.

Consistent with prior research, prior payout ratios (LagCashD), capital adequacy $(C F)$, and prior profitability (LagROA) have positive effects on the dividend payout ratios. The growth opportunities $(G R O W)$, and debt ratio $(D E B T)$ report negative influence on the dividend payout ratios. We also find that profitability (ROA) has negative influence on the dividend payout ratios and the ownership of major shareholders (STOCK) have positive effects.

Table 3. Regression results on dividend payout ratios

\begin{tabular}{lrrrr}
\hline Variable & $\begin{array}{r}\text { Estimated } \\
\text { parameter }\end{array}$ & $\begin{array}{r}\text { Standard } \\
\text { error }\end{array}$ & t-value & p-value \\
\hline Intercept & 117.91 & 24.34 & 4.84 & $<0.01$ \\
YEAR & 10.01 & 3.48 & 2.88 & $<0.01$ \\
DivP & 0.01 & 0.01 & 1.37 & 0.17 \\
LagCashD & 0.09 & 0.03 & 2.97 & $<0.01$ \\
GROW & -0.10 & 0.05 & -2.06 & 0.04 \\
FCF & 0.24 & 0.22 & 1.09 & 0.27 \\
CF & 0.19 & 0.11 & 1.78 & 0.08 \\
SIZE & -0.65 & 1.52 & -0.43 & 0.67 \\
DEBT & -0.72 & 0.13 & -5.72 & $<0.01$ \\
ROA & -3.86 & 0.42 & -9.13 & $<0.01$ \\
LagROA & 1.27 & 0.34 & 3.74 & $<0.01$ \\
STOCK & 0.35 & 0.16 & 2.16 & 0.03 \\
P_APP & 0.04 & 0.67 & 0.06 & 0.95
\end{tabular}




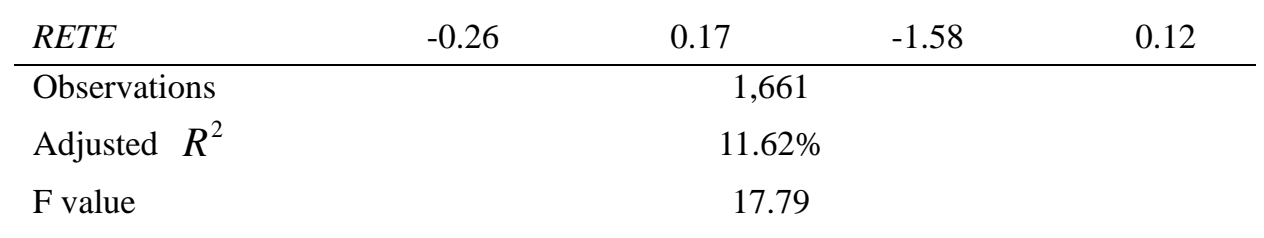

Please see Table 1 for variable definitions.

Tables 4 shows the regression results on the dividend payout ratios once the interaction terms are incorporated in the models. The F-values is still statistically significant under the $1 \%$ significance level. The coefficient of YEAR is also positive and statistically significant under the 5\% significance level. However, the coefficients of DivP and the product of DivP and YEAR are both statistically insignificant under the $10 \%$ significance level. This result indicates that the companies with stable dividends do not engage in tax planning before and after the ACT. Therefore, $\mathrm{H} 2$ is also supported. In addition, all control variables are essentially unchanged. None of the VIF values for coefficients exceeds the 10 threshold, indicating the absence of collinearity between independent variables.

Table 4. Regression results on dividend payout ratios -Incorporating the interaction terms

\begin{tabular}{|c|c|c|c|c|}
\hline Variable & $\begin{array}{l}\text { Estimated } \\
\text { parameter }\end{array}$ & $\begin{array}{r}\text { Standard } \\
\text { error } \\
\end{array}$ & t-value & p-value \\
\hline Intercept & 118.31 & 24.35 & 4.86 & $<0.01$ \\
\hline YEAR & 8.75 & 3.81 & 2.29 & 0.02 \\
\hline $\operatorname{Div} P$ & 0.01 & 0.01 & 0.62 & 0.53 \\
\hline $\operatorname{Div} P \times Y E A R$ & 0.03 & 0.04 & 0.81 & 0.42 \\
\hline LagCashD & 0.10 & 0.03 & 3.02 & $<0.01$ \\
\hline GROW & -0.10 & 0.05 & -2.05 & 0.04 \\
\hline$F C F$ & 0.23 & 0.22 & 1.07 & 0.29 \\
\hline$C F$ & 0.19 & 0.11 & 1.77 & 0.08 \\
\hline SIZE & -0.68 & 1.53 & -0.44 & 0.66 \\
\hline$D E B T$ & -0.72 & 0.13 & -5.70 & $<0.01$ \\
\hline$R O A$ & -3.85 & 0.42 & -9.11 & $<0.01$ \\
\hline LagROA & 1.27 & 0.34 & 3.76 & $<0.01$ \\
\hline STOCK & 0.35 & 0.16 & 2.15 & 0.03 \\
\hline$P \_A P P$ & 0.05 & 0.67 & 0.08 & 0.94 \\
\hline RETE & -0.26 & 0.17 & -1.58 & 0.12 \\
\hline Observations & \multicolumn{4}{|c|}{1,661} \\
\hline Adjusted $R^{2}$ & \multicolumn{4}{|c|}{$11.60 \%$} \\
\hline F value & \multicolumn{4}{|c|}{16.56} \\
\hline
\end{tabular}

Please see Table 1 for variable definitions.

Our results are in line with those findings that tax change altered dividend policies (Jacob and Jacob, 2013). Studies on countries that use an imputation income tax system also have similar results (Alstadsater \& Fjarli, 2009; Korkeamaki et al., 2010; Kaserer et al., 2012). Alstadsater and Fjarli (2009) argue strong timing effects on dividend payout after increasing top marginal tax rates of the Norwegian on individual dividend income. Finland abolished the full imputation system and introduced a partial double taxation system of corporate income. Korkeamaki et al. (2010) document that Finnish firms altered their dividend policies based on the changed tax incentives of large shareholders. Likewise, the German government replaced the tax credit system with full imputation by the half-income system. 
Kaserer et al., (2012) find that the act reduced both the propensity to pay dividends as well as their size. However, consistent with Brav et al. (2008), we find that firms with stable dividend policy are reluctant to change their dividend payouts.

\subsection{Robustness Tests}

To check the sensitivity of our findings to the measurements of the growth opportunities (GROW), capital adequacy $(C F)$, and firm sizes (SIZE), we replace those control variables with market-to-book value of equity, ratio of cash and short-term investments to total assets, and natural logarithm of firm's market value. Our results remain unchanged.

\section{Conclusions}

The cut in tax credits from 100\% to 50\% under the imputation tax system in Taiwan in 2015 means that shareholders can only enjoy $50 \%$ tax credits for the income taxes paid by the companies who issue dividends to the shareholders. This paper intends to examine whether the dividend payout ratios are influenced by this tax reform. Especially for those companies noted for stable dividends. The research findings suggest that the dividend payout ratios declines following the reduction in tax credits, implying that the sampled companies do facilitate the tax planning for shareholders during the tax reform. Meanwhile, the study finds that the companies offering stable dividends do not engage in tax planning before and after the cut in tax credits by altering their dividend payout ratios.

This paper fills in the gap of existing literature and the research findings can serve as a template for tax planning by the competent authorities and the legislative agencies in the scenario planning for likely responses by companies. The series of tax reforms over recent years in Taiwan have a profound impact on the companies. However, there have not been many relevant academic studies. This paper hopes its findings can shed light to the effects of tax reforms and have implications for the government and the academics.

\section{References}

Allen, F., Bernardo, A., \& Welch, I. (2000). A theory of dividends based on tax clientele. The Journal of Finance, 55(6), 2499-2536. https://doi.org/10.1111/0022-1082.00298

Alli, K. L., Khan, A. Q., \& Ramirez, G. G. (1993). Determinants of corporate dividend policy: A factorial analysis. The Financial Review, 28(4), 523-547. https://doi.org/10.1111/j.1540-6288.1993.tb01361.x

Alstadsater, A., \& Fjarli, E. (2009). Neutral taxation of shareholder income? Corporate responses to an announced dividend tax. International Tax and Public Finance, 16(4), 571-604. https://doi.org/10.1007/s10797-009-9107-2

Anderson, D. R., Sweeney, D. J., \& Williams, T. A. (1999). Statistics for business and economics (7th ed.). Cincinnati, OH: South Western College Pub.

Baker, H. K., Farrelly, G. E., \& Edelman, R. B. (1985). A survey of management views on dividend policy. Financial Management, 14(3), 78-84. https://doi.org/10.2307/3665062

Brav, A., Graham, J. R., Harvey, C. R., \& Michaely, R. (2008). Managerial response to the May 2003 dividend tax cut. Financial Management, 37(4), 611-624. https://doi.org/10.1111/j.1755-053X.2008.00027.x

Brown, K., \& Sum, V. (2010). Determinants of dividend payments. International Journal of Applied Accounting and Finance, 1(1), 40-46.

Daunfeldt, S., Selander, C., \& Wikstrom, M. (2009). Taxation, dividend payments and ex-day price changes. Multinational Finance Journal, 13(1/2), 135-154. https://doi.org/10.17578/13-1/2-6

DeAngelo, H., DeAngelo, L., \& Stulz, R. M. (2006). Dividend policy and the earned/contributed capital mix: A test of the life-cycle theory. Journal of Financial Economics, 81, 227-254. https://doi.org/10.1016/j.jfineco.2005.07.005

Dhaliwal, D., \& Wang, S. (1992). The effect of the book income adjustment in 1986 alternative minimum tax on corporate financial reporting. Journal of Accounting and Economics, 15(1), 7-26. https://doi.org/10.1016/0165-4101(92)90010-Y

Gramlich, J. D. (1991). The effect of alternative tax book income adjustment on accrual decisions. Journal of the American Taxation Association, 13, 36-56.

Guenther, D. A. (1994). Earnings management in response to corporate tax rate changes: Evidence from the 1986 Tax Reform Act. The Accounting Review, 69(1), 230-243.

Hoque, A. (2018). Impulse of dividend payment decision: Evidence from pharmaceutical industry in Bangladesh. International Journal of Financial Research, 9(1), 219-225. https://doi.org/10.5430/ijfr.v9n1p219 
Howton, S., \& Howton, S. (2006). The corporate response to the 2003 dividend tax cut. Journal of Applied Finance, $16(1), 62-71$.

Jacob, M., \& Jacob, M. (2013). Taxation, dividends, and share repurchases: Taking evidence global. Journal of Financial and Quantitative Analysis, 48(4), 1241-1269. https://doi.org/10.1017/S0022109013000367

Jensen, M. C. (1986). Agency costs of free cash flow, corporate finance, and takeovers. The American Economic Review, 323-329.

Kaserer, C., Rapp, M. S., \& Trinchera, O. (2012). Payout policy, taxes, and corporate insiders: Evidence from the German Tax Reform 2001. Journal of Business Economics, 82(s5), 85-114. https://doi.org/10.1007/s11573-012-0596-6

Khoury, N., \& Smith, K. (1977). Dividend policy and the capital gains tax in Canada. Journal of Business Administration, 11, 19-37.

Korkeamaki, T., Liljeblom, E., \& Pasternack, D. (2010). Tax reform and payout policy: Do shareholder clienteles or payout policy adjust?. Journal of Corporate Finance, 16(4), 572-587. https://doi.org/10.1016/j.jcorpfin.2009.12.003

Lasfer, M. A. (1996). Taxes and dividends: The UK evidence. Journal of Banking \& Finance, 20(3), 455-472. https://doi.org/10.1016/0378-4266(95)00012-7

Lie, E., \& Lie, H. (1999). The role of personal taxes in corporate decisions: An empirical analysis of share repurchases and dividends. Journal of Financial and Quantitative Analysis, 34, 533-552. https://doi.org/10.2307/2676233

Lintner, J. (1956, May). Distribution of incomes of corporations among dividends, retained earnings, and taxes. American Economic Review, 46, 97-113.

Lopez, T., Reiger, P., \& Lee, T. (1998). Identifying tax-induced earnings management around TRA86 as a function of prior tax-aggressive behavior. The Journal of the American Taxation Association, 20(2), 37-56.

Manzon, G. B. Jr. (1992). Earnings management of firms subject to the alternative minimum tax. The Journal of American Taxation Association, 88-111.

Maydew, E. (1997). Tax-induced earnings management by firms with NOLs. Journal of Accounting Research, 35(1), 83-96. https://doi.org/10.2307/2491468

Mitton, T. (2004). Corporate governance and dividend policy in emerging markets. Emerging Markets Review, 5(4), 409-426. https://doi.org/10.1016/j.ememar.2004.05.003

Moser, W. (2007). The effect of shareholder taxes on corporate payout choice. Journal of Financial and Quantitative Analysis, 42, 991-1019. https://doi.org/10.1017/S0022109000003471

Nam, J., Wang, J., \& Zhang, G. (2010). The impact of the dividend tax cut and managerial stock holdings on corporate dividend policy. Global Finance Journal, 21, 275-292. https://doi.org/10.1016/j.gfj.2010.09.005

Papaioannou, G. J., \& Savarese, C. M. (1994). Corporate dividend policy response to the Tax Reform Act of 1986. Financial Management, 23(1), 56-63. https://doi.org/10.2307/3666056

Pattenden, K., \& Twite, G. (2008). Taxes and dividend policy under alternative tax regimes. Journal of Corporate Finance, 14(1), 1-16. https://doi.org/10.1016/j.jcorpfin.2007.09.002

Poterba, J. M., \& Summers, L. (1984). New evidence that taxes affect the valuation of dividends. Journal of Finance, 39(5), 1397-1415. https://doi.org/10.1111/j.1540-6261.1984.tb04914.x

Scholes, M., Wilson, G., \& Wolfson, M. (1992). Firms' responses to anticipated reductions in tax rates: The Tax Reform Act of 1986. Journal of Accounting Research, 30(Supplement), 161-185. https://doi.org/10.2307/2491200

Thanatawee, Y. (2011). Life-cycle theory and free cash flow hypothesis: Evidence from dividend policy in Thailand. International Journal of Financial Research, 2(2), 52-60. https://doi.org/10.5430/ijfr.v2n2p52

Wang, C., \& Guo, Y. (2011). Do dividend tax cuts lead firms to increase dividends: Evidence from China. China Journal of Accounting Research, 4(4), 197-209. https://doi.org/10.1016/j.cjar.2010.06.001

Wang, S. W. (1994). The relationship between financial reporting practices and the 1986 alternative minimum tax. The Accounting Review, 69, 495-506. 